\title{
Composition and Physicochemical Characteristics of Milk of the West African Dwarf Goats in Cross River, Nigeria
}

\author{
Ebegbulem, Victoria N. ${ }^{1^{*}}$ and Nwanjoku, Janet E. ${ }^{1}$ \\ ${ }^{1}$ Department of Animal Science, University of Calabar, Nigeria.
}

\begin{abstract}
Authors' contributions
This work was carried out in collaboration between both authors. Author NEV designed the study, performed the statistical analysis, wrote the protocol and wrote the first draft of the manuscript. Author ENJ collected milk samples, ran the composition analysis and managed the literature searches. Both authors read and approved the final manuscript.
\end{abstract}

Article Information

DOI: 10.9734/ARRB/2021/v36i730402 Editor(s):

(1) Prof. Ibrahim Farah, Jackson State University, USA.
Reviewers:

(1) Kgantjie W. Moloto, South Africa. (2) Fatma ILHAN, Selcuk Universty, Turkey. (3) M. A. Snyman, Grootfontein Agricultural Development Institute, South Africa. Complete Peer review History: https://www.sdiarticle4.com/review-history/69849

Original Research Article

Received 15 April 2021

Accepted 21 June 2021

Published 29 July 2021

\section{ABSTRACT}

Goat milk is a suitable alternative to human milk owing to its high beta casein content which makes it very digestible unlike cow milk. Moreover, the West African Dwarf goat is highly trypano- tolerant and thrives excellently in the humid forest zone of Nigeria. It therefore necessitated the need to expound its potential in human nutrition in the study area. The objectives of the study were to evaluate the proximate, mineral composition and physicochemical characteristics of milk of West African Dwarf goats in Cross River State, Nigeria .Twenty five lactating West African Dwarf does within the age of 3-5 years were milked from five Local Government Areas of Cross River State (Calabar South, Calabar Municipal, Akamkpa, Biase and Odukpani) in which three goat milk samples were obtained by hand milking from each location. Data collected were presented using descriptive statistics. Completely randomized design was used to study the relationship between components of the milk samples. Proximate components of milk were crude protein (3.91-6.35\%), ether extract (2.69-5.04\%), Ash (1.51-1.95\%), Nitrogen free extract (88.68-90.32\%) and moisture content (77.72-85.56\%). Values of physicochemical components were: Total Acid $(0.16-0.21 \%)$, 
Total solid (12.30-13.30\%), Density (0.90-1.95\%) and $\mathrm{pH}$ (6.50-6.90\%). Elemental components $(\mathrm{mg} / 100 \mathrm{~g})$ were potassium (202-64-204.39), sodium (49.06-49.96), calcium (133.18-133.98), magnesium (13.96-14.07), iron (0.04-0.07), zinc (0.30-0.32) copper (1.32-1.35) and phosphorus (110.32-110.98). Proximate composition of milk samples from the different locations varied significantly $(p>0.05)$. Similarly, the physicochemical composition from the locations also varied significantly $(p<0.05)$ with exception to milk $\mathrm{pH}$ with no significant difference. Mineral elements of milk samples from different locations were not significantly different except the potassium content in milk from Odukpani which was significantly lower than the other locations. Goat milk from the study locations met the nutritional standards in terms of proximate, mineral and physicochemical composition. Results from this research provides veritable information of the nutritional content of goat milk in the study locations particularly and help encourage the incorporation of goat milk in the diet of Nigerians generally.

Keywords: Mineral; proximate; components; nutrition.

\section{INTRODUCTION}

Goats thrive in diverse climatic conditions which favor their rearing in all the regions of Nigeria but this advantage has not been harnessed with respect to dairy production. The West African Dwarf goat is more trypano-tolerant than other local breeds and thrives in tsetse infested Southern Nigeria, making it the breed of choice for probable improvement as a dairy goat especially in the study area. Despite the low level of milk yield by West African Dwarf goats, if improved, can provide cheaper source of milk to supplement cow milk.

Milk constitutes a vital ingredient in human nutrition. The components of raw milk vary by species and by a number of other factors like nutrition, breed, parity and environment. Milk contains significant amount of protein for body growth and tissues repair: as well as minerals and vitamins. Goat milk, like cow milk, have four species of $\alpha_{\mathrm{s} 1}\left(\right.$ alpha $\left._{\mathrm{s} 1}\right), \alpha_{\mathrm{s} 2}\left(\right.$ alpha $\left._{\mathrm{s} 2}\right), \beta$ (beta) and $\mathrm{K}$ (kappa) casein [1] and an excellent alternative to cow milk. Goat milk is comparatively higher in beta casein content unlike cow milk which has more of alpha casein [2]. This difference contributes to the soft curd forming property, better digestibility and less paediatric allergy of the goat milk [3]. Goat milk with its low level of $\alpha_{\mathrm{S} 1}$ casein with a higher proportion of $\beta$ casein is closer to human milk than cow milk, therefore a more suitable supplement. Mineral content of goat milk is within the range of $0.70-0.85 \%$, has more calcium, phosphorus and potassium similar vitamin content as cow and human milk [4].

Goat milk is more digestible, alkaline and possesses better buffering capacity than cow milk and believed to as well possess certain therapeutic virtues in medicine and human nutrition [5]. Bihaqi and Jalal [3] asserted that goat milk has higher calcium, phosphorus and potassium content than cow and human milk. In addition, Kumar et al. [2] reported that goat milk possesses simple lipids like diacylglycerols, monoacylglycerols and cholesterol esters, complex lipids (phospholipids) and liposoluble compounds (sterols, cholesterol esters, hydrocarbons). Similarly, Non- protein nitrogen (NPN) contents of goat milk is higher than in cow or human milk [5]. According to Herian (2008) in Warsama and El Zubeir [6], goat milk averagely contains $12.6 \%$ solids, $3.4 \%$ protein, $3.8 \%$ lactose and $0.8 \%$ minerals. Cross bred Saanen $\times$ Nubian goat milk was reported to contain $4.173 \%$ fat, $3.66 \%$ protein, $4.914 \%$ lactose, $0.733 \%$ ash and $13.48 \%$ total solids [7].

A major drawback to the consumption of goat milk by many individuals is the 'goaty' flavor. In Nigeria, there is inadequate consumption of milk as majority of the populace rely solely on cow milk which is to a large extent imported into the country. Therefore, the dearth of milk and its byproducts could be ameliorated by the improved management and exploitation of the goat.

This research sought to determine the mineral composition and physicochemical characteristics of milk of West African Dwarf goats in Cross river State, Nigeria.

\section{MATERIALS AND METHODS}

\subsection{Locations of Milk Collection}

Collection of goat milk was conducted in 5 locations in Cross River State, Nigeria (Calabar South, Calabar Municipal, Akamkpa, Biase and 
Odukpani Local Government Areas). Five samples of West African Dwarf goat milk from each location was collected into sterile bottles by hand milking.

\subsection{Experimental Management}

Animals

and

Milk samples used for analysis were obtained from 25 lactating West African Dwarf does between the ages of 3 and 5 years. Samples were obtained from five does in each of the five (5) experimental areas. Age of goats was determined by observing the dentition of the does.

\subsection{Management System}

Experimental animals were raised on the semiintensive system of goat production. Shelter was provided at night, goats were allowed to graze for 3-5 hours every day within the environment and stall fed.

\subsection{Proximate Analysis}

Samples were analyzed for proximate composition according to standard procedures [8]. Fat content of the samples was measured by Gerber method [8], moisture content using Ovendrying method, ash content was determined by Furnace-Drying method, while protein content was determined by digestion, distillation and titration method. Carbohydrate content was calculated based on the differences between $100 \%$ drymatter and sums of percentages fat, moisture, ash and protein contents of milk samples.,

\subsection{Statistical Analysis}

Data obtained was presented using descriptive statistics. Completely Randomized Design (CRD) was used to analysis the data on a One Way Analysis of Variance. Means were separated using Least Significant Differences [9].

\section{RESULTS AND DISCUSSION}

Results of the proximate composition of milk samples for the five locations are shown in Table 1. The highest crude protein (CP) content was obtained from goats in Odukpani LGA while the least $\mathrm{CP}$ value was obtained from goats in Biase LGA. Crude Protein content of Odukpani and Calabar South LGA goats were statistically ( $p>0.05)$ similar $(6.35 \%$ and $6.20 \%$ respectively) but were higher than the other three locations. The values of CP obtained in this study (4.20$6.35 \%$ ) is in agreement with $4.5 \%$ obtained by Warsama et al. [6] in Sudanese goats but highly differ with the reports of Zahraddeen et al. [10] and Kumar et al. [2] who obtained average values of $3.27 \%$ and $3.52 \%$ respectively. These differences could be attributed to differences in the nutrition, age and location used of the study.

Milk samples obtained from Calabar Municipal LGA were significantly $(P<0.05)$ higher in Ether Extract (EE) content whereas the least was obtained from Calabar South LGA. Samples from Odukpani and Akamkpa LGAs were statistically $(P>0.05) \quad$ similar but significantly $(p<0.05)$ different from Calabar South samples. The average value from the present study $(3.93 \%)$ is in agreement with that of Gajewska et al. [11] who reported an average value of $3.9 \%$. The values of ash content obtained in the present study $(1.51-1.95 \%)$ are at variance with the reports of $(0.70 \%$ and 0.865$)$ by Zahraddeen et al. [10] and Kumar et al. [2] respectively. Values for Nitrogen Free Extract (NFE) ranged from $88.81-90.32 \%$. Maximum level of moisture content was obtained from milk samples of goats from Biase and the least from Calabar South LGAs respectively.

Table 1. Proximate composition of milk samples from West African Dwarf goat in Cross River State, Nigeria

\begin{tabular}{llllllll}
\hline $\begin{array}{l}\text { Parameters } \\
\%\end{array}$ & Odukpani & $\begin{array}{l}\text { Cal. } \\
\text { South }\end{array}$ & $\begin{array}{l}\text { Cal. } \\
\text { Municipal }\end{array}$ & Akamkpa & Biase & Sed & P.Value \\
\hline Crude protein & $6.35^{\mathrm{a}}$ & $6.20^{\mathrm{a}}$ & $4.92^{\mathrm{b}}$ & $4.20^{\mathrm{b}}$ & $3.91^{\mathrm{b}}$ & 0.57 & 0.004 \\
Ether extract & $3.85^{\mathrm{b}}$ & $2.69^{\mathrm{c}}$ & $5.04^{\mathrm{a}}$ & $3.83^{\mathrm{b}}$ & $4.22^{\mathrm{b}}$ & 0.35 & 0.001 \\
Crude fibre & 0.00 & 0.00 & 0.00 & 0.00 & 0.00 & 0.00 & 0.00 \\
Ash & $1.95^{\mathrm{a}}$ & $1.51^{\mathrm{b}}$ & $1.70^{\mathrm{ab}}$ & $1.75^{\mathrm{ab}}$ & $1.89^{\mathrm{a}}$ & 0.14 & 0.08 \\
Nitrogen free extract & $88.81^{\mathrm{ab}}$ & $89.53^{\mathrm{ab}}$ & $88.68^{\mathrm{b}}$ & $90.32^{\mathrm{a}}$ & $89.95^{\mathrm{ab}}$ & 0.78 & 0.23 \\
Moisture & $81.28^{\mathrm{ab}}$ & $77.72^{\mathrm{b}}$ & $79.14^{\mathrm{b}}$ & $82.99^{\mathrm{ab}}$ & $85.56^{\mathrm{a}}$ & 2.99 & 0.15 \\
\hline \multicolumn{6}{c}{ a,b,c = means on the same row with different superscripts are significantly different $(P>0.05)}$.
\end{tabular}


The results of the physicochemical composition of the milk samples are shown in Table 2.

The result of the experiments for physicochemical composition of milk samples from West African Dwarf goats from different locations in Cross River state of Nigeria shows that there were significant differences for the following parameters: total acid, total solids and density but there were no significant differences in $\mathrm{pH}$ of milk samples obtained from the different locations. The values for total acid $(0.16-0.21 \%)$ were in agreement with the report $(0.16 \%)$ of Asif et al. [12] and $0.15 \%$ by Warsama et al. [6]. The values for total solids (12.50-13.30\%) obtained in the present research were close to the average value (12.84\%) reported by Asif et al. [12] and $13.00 \%$ by Kumar et al. [2]. However, there was no significant differences for the $\mathrm{pH}$ of milk samples from the different locations. The values from the research varied slightly from the report of Zahraddeen et al. [10] who obtained a value of $6.21 \%$.

Table 3 shows the mineral content of goat milk samples from the five locations. There was no significant $(p<0.05)$ difference in potassium content of milk samples from the locations except that of Odukpani LGA. Milk samples from Calabar South had the highest value of $204.39 \mathrm{mg} / 100 \mathrm{~g}$ and Odukpani with the least of $202.64 \mathrm{mg} / 100 \mathrm{~g}$. The values for potassium (202.64-204.39mg/100g) in the present study were higher than $96-846 \mathrm{mg} / 100 \mathrm{~g}$ reported by Gajewska et al. [11] and $121 \mathrm{mg}$ by Kumar et al. [2]. However, there were no significant differences for other parameters such as sodium, calcium, magnesium, iron, zinc, copper and phosphorus..06mg/100g. The values for Sodium ranging from 49.06-49.96 were lower than the values $(27-40.7 \mathrm{mg} / 100 \mathrm{~g})$ reported by Gajewska et al. [11] but similar to $41 \mathrm{mg}$ reported by Kumar et al. [2]. This disparity could be attributed to the quality of feeding materials as goats in Odukpani, a rural area, were probably exposed to better quality feed than those in urban Calabar Municipal. The values for calcium ranging from $133.18-133.98 \mathrm{mg} / 100 \mathrm{~g}$ were lower than the report $(220 \mathrm{mg} / 100 \mathrm{~g})$ of Midau et al. [13]. The values for magnesium obtained in the present study ranging from $13.96-14.07 \mathrm{mg} / 100 \mathrm{~g}$ were in tandem with the report of Park et al. [14] but differed from observation of Midau et al. [13]. The value for Iron in this research is in consonance with the report of Gajewska et al. [11].

The Zinc content values obtained in this study $(0.30-0.32 \mathrm{mg} / 100 \mathrm{~g})$ were lower than values reported by previous authors $[11,14]$. The values for $\mathrm{Cu}$ ranging from $1.32-1.35 \mathrm{mg} / / 100 \mathrm{~g}$ were higher when compared to those (0.02$0.08 \mathrm{mg} / 100 \mathrm{~g}$ ) reported by Gajewska et al. [11]. The values for phosphorus ranging from 110.32$110.98 \mathrm{mg} / 100 \mathrm{~g}$ were lower when compared to

Table 2. Physicochemical composition of milk samples of West African dwarf goat in Cross River State, Nigeria

\begin{tabular}{llllllll}
\hline $\begin{array}{l}\text { Parameters } \\
\%\end{array}$ & Odukpani & Cal. South & $\begin{array}{l}\text { Cal. } \\
\text { Municipal }\end{array}$ & Akamkpa & Biase & Sed & P.Value \\
\hline Total Acid & $0.17^{\mathrm{bc}}$ & $0.16^{\mathrm{c}}$ & $0.20^{\mathrm{a}}$ & $0.21^{\mathrm{a}}$ & $0.18^{\mathrm{b}}$ & 0.01 & 0.006 \\
Total Solid & $12.90^{\mathrm{b}}$ & $12.30^{\mathrm{d}}$ & $12.50^{\mathrm{c}}$ & $12.80^{\mathrm{b}}$ & $13.30^{\mathrm{a}}$ & 0.07 & $<0.001$ \\
Density & $0.90^{\mathrm{c}}$ & $0.91^{\mathrm{c}}$ & $0.95^{\mathrm{a}}$ & $0.92^{\mathrm{bc}}$ & $0.93^{\mathrm{b}}$ & 0.01 & 0.001 \\
pH & 6.60 & 6.90 & 6.80 & 6.70 & 6.50 & 0.01 & 0.001 \\
\hline
\end{tabular}

Table 3. Mineral elements (mg/100g dry matter) of milk sample from West African Dwarf Goat in south southern Nigeria

\begin{tabular}{llllllll}
\hline Parameters & Odukpani & Cal. South & Cal. Municipal & Akamkpa & Biase & Sed & P.Value \\
\hline Potassium (K) & $202.64^{\mathrm{b}}$ & $204.39^{\mathrm{a}}$ & $204.03^{\mathrm{a}}$ & $203.47^{\mathrm{a}}$ & $203.62^{\mathrm{a}}$ & 0.71 & 0.219 \\
Sodium (Na) & 49.41 & 49.93 & 49.06 & 49.63 & 49.96 & 0.52 & 0.432 \\
Calcium (Ca) & 133.98 & 133.27 & 133.18 & 133.67 & 133.97 & 0.92 & 0.848 \\
Magnesium (Mg) & 14.03 & 13.97 & 14.07 & 14.06 & 13.96 & 0.22 & 0.98 \\
Iron (Fe) & 0.06 & 0.04 & 0.04 & 0.04 & 0.07 & 0.02 & 0.353 \\
Zinc (Zn) & 0.32 & 0.30 & 0.32 & 0.32 & 0.32 & 0.02 & 0.775 \\
Copper (Cu) & 1.35 & 1.32 & 1.32 & 1.32 & 1.33 & 0.2 & 0.368 \\
Phosphorus (P) & 110.53 & 110.73 & 110.32 & 110.64 & 110.98 & 0.53 & 0.784 \\
\hline
\end{tabular}


those reported by Midau et al. [13] ( 130 $\mathrm{mg} / 100 \mathrm{~g})$. The differences could be attributed to management system, age, location of studies, breed and stages of lactation. From the results, It is observed that there were no significant differences for all the mineral elements except in potassium (k) where the content in milk samples from Odukpani differed significantly $(p>0.05)$ from the other four locations.

\section{CONCLUSION}

Goat milk from the study locations met the nutritional standards in terms of proximate, mineral and physicochemical composition. Results from this research provide veritable information of the nutritional content of goat milk in the study locations particularly and will help encourage the incorporation of goat milk in the diet of Nigerians generally.

\section{COMPETING INTERESTS}

Authors have declared that no competing interests exist.

\section{REFERENCES}

1. Yadav AK, Singh J, Yadav SK. Composition, nutritional and therapeutic values of goat milk: a review. Asian Journal of Dairy \& Food Research. 2016;35(2):96-102.

2. Kumar S, Kumar B, Kumar R, Kumar S, Khatkar SK, Kanawjia SK. Nutritional features of goat milk- a review. Indian Journal of Dairy Science. 2012;65(4):266273.

3. Bihaqi SF, Jalal H. Goaty odour in milk and its prevention. Research Journal of Agricultural Science. 2010;1:487-490.

4. Silanikove N, Leitner G, Merin U, Prosser CG. Recent advances in exploiting goat's milk: quality, safety and production aspects. Small Ruminants Research. 2010;89:110-124.
5. Jooyandeh $\mathrm{H}, \quad$ Aberoumand $\mathrm{A}$. Physicochemical, nutritional, heat treatment effects and dairy aspects of goat and sheep milks. World Applied Science Journal. 2010;11:1316-1322.

6. Warsama LM, El Zubeir IYM. Evaluation of chemical composition and hygienic quality of goat milk in Khartoum State, Sudan. Annals of Food Science and Technology. 2016;17(2):404-410.

7. Abd El Gadir ME, El Zubeir IEM. Production performance of cross bred (Saneen $x$ Nubian) goats in the second kidding under sudan conditions. Pakistan Journal of Biological Sciences. 2005; 8(5):734-739.

8. Association of the Official Analytical Chemist (AOAC) $18^{\text {th }}$ Edition, Gaithersburg MD, USA; 2005.

9. Steel RGD, Torrie JH. Principles of statistics. A biometrical approach. $2^{\text {nd }}$ edition. McGraw-Hill Book company; 1980.

10. Zahraddeen D, Butswat ISR, Mbap ST. Evaluation of some factors influencing growth performance of local goats in Nigeria. African Journal of Food Agriculture Nutrition and Development. 2008;8(4):464-479.

11. Gajewska R, Rocz Panstw Zekl Hig. Evaluation of Health aspect of goat Milk. Roez Panstw Zakl \& Hig. 1996;49(3):295301.

12. Asif M, Usman S. A comparative study on the physicochemical parameter of sample collected from bufflar, cow, goat and sheep. Department of Chemistry University of Gujrat, Gujrat Pakistan; 2010.

13. Midau A, Kibon A, Moroppa SM, Augustine C. Influence of season on milk yield and milk composition of Red Sokoto Goats in Mubi Area of Adamawa State, Nigeria. International Journal of Dairy Science. 2010;5(3):135-141.

14. Park YW, Juarez $M$, Ramos $M$, Haenlein GFW. Physicochemical characteristics of goat and sheep milk. Small Ruminant Research. 2007;68:88-113.

(C) 2021 Victoria and Janet; This is an Open Access article distributed under the terms of the Creative Commons Attribution License (http://creativecommons.org/licenses/by/4.0), which permits unrestricted use, distribution, and reproduction in any medium, provided the original work is properly cited.

Peer-review history:

The peer review history for this paper can be accessed here: https://www.sdiarticle4.com/review-history/69849 